\title{
Equity crowdfunding and financial literacy of individual investors in Japan
}

\author{
Masatoshi Fujii, Chie Hosomi and Yoshiaki Nose \\ Graduate School of Business, Doshisha University, Kyoto, Japan
}

\begin{abstract}
Purpose - This study aims to fill the gap in previous research that focuses on the superficial aspects of equity crowdfunding (ECF) campaigns and financial practices by examining financial literacy aspects, such as due diligence and valuation, in terms of factors that influence Japanese individual investors' investments in ECF. Design/methodology/approach - The status of information disclosure in ECF campaigns is checked. In addition, the feasibility of the initial due diligence and valuation using this information is verified. Specifically, the lack of financial literacy hypothesis is developed and (1) expected market capitalization in the final fiscal year of the business plan and (2) expected returns on investment (IRR: internal rate of return) are estimated. Findings - ECF campaigns in Japan disclose information equivalent to that obtained by professional venture capitalists. Analysis of the disclosed business plan allows for initial due diligence and valuation. By contrast, due diligence reveals that some projects are unlikely to be listed even if their business plans are met, and others have low IRRs. In addition, a stock acquisition rights project, in which even professional investors are unable to calculate IRRs, is completed at the same rate as a common stock project; this suggests that individual investors lack financial literacy.
\end{abstract}

Originality/value - Analyzing ECF from financial literacy aspects, such as due diligence and valuation, is unique. Such aspects are essential for private equity investments but have not been addressed in previous studies.

Keywords Equity crowdfunding, Financial literacy, IRR (Internal rate of return)

Paper type Research paper

\section{Introduction}

Recently, individuals' money for investments has begun to be collected through crowdfunding, which raises funds from a large, unspecified number of people through the Internet (Bruton et al., 2015; Drover et al., 2017). Given lingering zero interest rates, a growing number of Japanese retail investors are seeking options for higher asset management returns. For this reason, a type of crowdfunding called equity crowdfunding (ECF) has emerged, even in Japan. This study focuses on ECF in Japan and develops preliminary suggestions regarding factors that individual investors have begun to actively consider. In recent years, ECF developed rapidly in Japan. According to our observations, almost 100 million yen (approximately US\$ 930,000) has been raised in tens of minutes through a number of campaigns. Another focus is the success rate of ECF. From May 2017 to January 2021, 235 ECF campaigns in Japan enjoyed a 70\% success rate. The gathering of individual investors in

(C) Masatoshi Fujii, Chie Hosomi and Yoshiaki Nose. Published in Journal of Capital Markets Studies. Published by Emerald Publishing Limited. This article is published under the Creative Commons Attribution (CCBY 4.0) license. Anyone may reproduce, distribute, translate and create derivative works of this article (for both commercial and non-commercial purposes), subject to full attribution to the original publication and authors. The full terms of this license may be seen at http://creativecommons. org/licences/by/4.0/legalcode

The authors sincerely thank Japan Cloud Capital, inc., for its permission to use the information necessary for this research.

Funding: This work was supported by JSPS KAKENHI Grant Number 19K01901.

\section{Japanese individual investors' investments}

Received 20 March 2021 Revised 8 June 2021 Accepted 9 June 2021

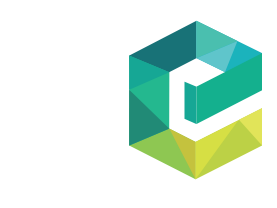

Journal of Capital Markets Studies Vol. 5 No. 1, 2021 Emerald Publishing Limited 2514-4774 DOI 10.1108/JCMS-03-2021-0007 
JCMS

5,1

6

high risk, unlisted stocks have surprised many people involved, and the phenomenon is necessary to clarify the mechanism.

Until now, investments in private equities have been made through professional investment channels, such as venture capital (VC) and business angel investors who conduct professional due diligence and discern the value of the issuer company. However, because due diligence for ECF must be performed by individual investors, many financial experts were skeptical about ECF spread in Japan (Matsuo, 2017b). When entrepreneurial finance investment decisions are made, all investors must examine business plans closely. Professional investors, such as venture capitalists, can sift through business plans (business due diligence), estimate appropriate share prices (valuation) and earn returns commensurate with their risk. They compete over their abilities. By contrast, most previous studies evaluated crowdfunding projects for superficial factors, such as a website's appearance, whether the product had a patent and manager background - no analysis included the due diligence and valuation that investors should conduct. This study reports the results of initial due diligence on ECF campaigns in Japan and valuations using the general VC method to bridge the gap between what is being done in entrepreneurial finance and what has been studied academically.

This study sets and verifies the lack of financial literacy hypothesis as the factor that activates ECF. Whether sufficient information is disclosed to individual investors and whether these investors sufficiently utilize that information are determined. The result of this analysis highlights the possibility that Japanese individual investors are not financially literate. If individual investors correctly improved their financial literacy of ECF, then they could enjoy more options for managing their financial assets and a better life through higher investment returns. From the issuer's viewpoint, ECF is a useful option, especially for companies in the seed or startup stage, in which financing is difficult and might contribute to new industry development. This study aims to contribute to ECF's long-term development by clarifying ECF-related issues and presenting relevant solutions.

\section{Market overview}

\section{What is equity crowdfunding?}

Five types of crowdfunding exist: donation, reward, lending, fund and ECF types (Hornuf and Neuenkirch, 2017; Lukkarinen et al., 2016; Adhikary et al., 2018). Funders seek different types of returns for each crowdfunding type. For example, investors demand certificates of appreciation for donations, goods and services for rewards, interest for lending, and dividends and capital gains for funds and ECF. Donation and purchase types of crowdfunding are regulated by different laws regarding receiving goods and services. Lending and fund-type crowdfunding and ECF are subject to the Financial Instruments and Exchange Law of Japan (Matsuo and Umemoto, 2015).

This law was revised in May 2015 to facilitate the use of ECF in Japan (Matsuo, 2017b). Because of the high distribution and credit risks associated with unlisted shares, the government mandates platform companies to obtain Type ISmall Amount Electronic Public Offering Service Provider licenses. The upper limit of issuer companies' annual procurement is regulated at 100 million yen, and the upper limit for individual investors' yearly investments is regulated at 500,000 yen per company. ECF is the last of the five types of crowdfunding to be introduced in Japan given the need for regulations that reflect risk.

\section{Overview of Japan's equity crowdfunding market}

Figure 1 provides the status of financing in Japan through ECF. Japan's ECF campaigns issue common stock or subscription rights to shares (subsequently described in detail). Figure 1a illustrates changes in the number of common stocks issued and the amounts raised. The amounts increased steadily after May 2017, when Japan's first project successfully raised 15 
Cumulative Count and Issue Value (Common stock)

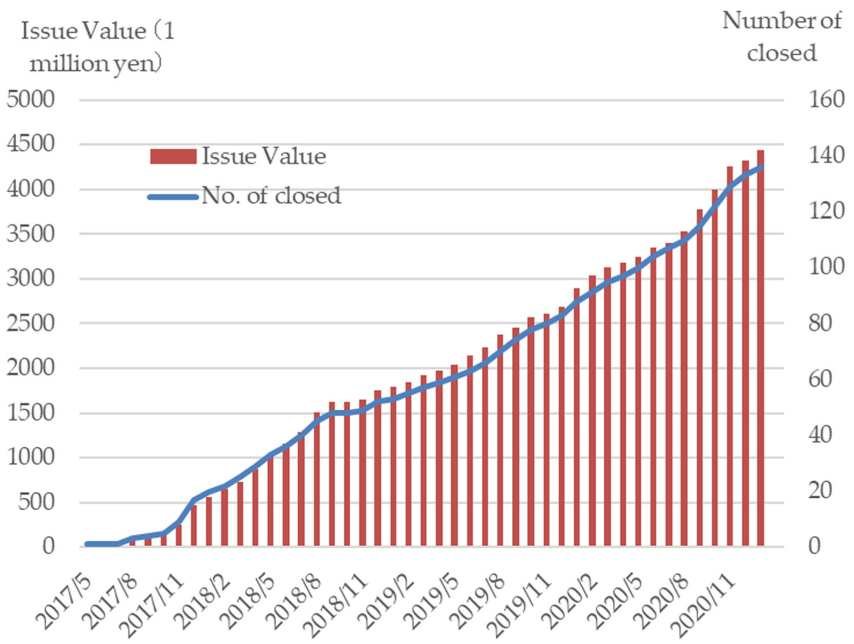

(a)

Cumulative Count and Issue Value (Stock acquisition rights)

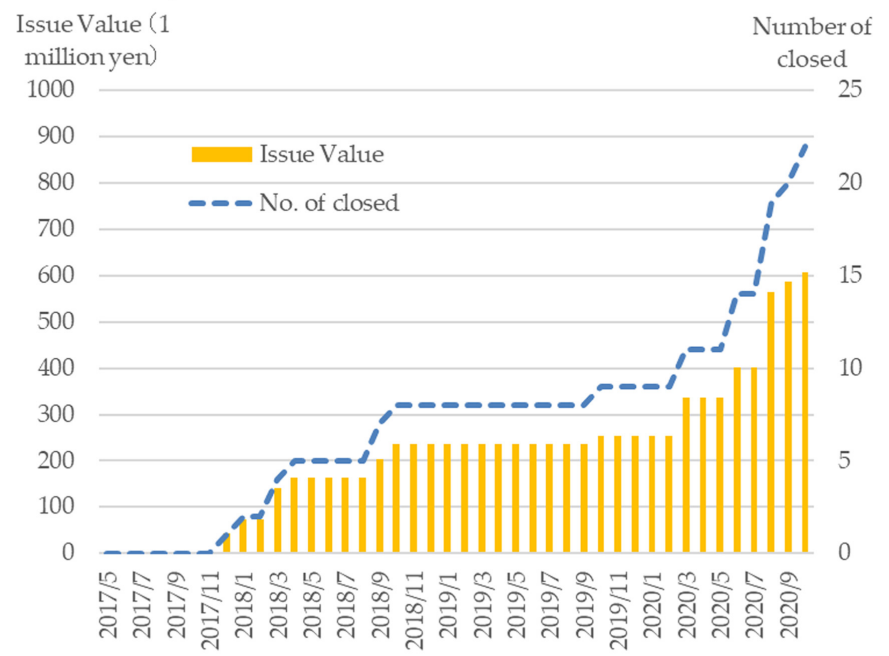

(b)

Note(s): The figure on the left (a) illustrates the number of contracts for common stock, and the figure on the right (b) illustrates the number of contracts for stock acquisition rights and the issue price. The horizontal axis indicates the year and month, and the vertical axis indicates the issue price ( 1 million yen) and number of transactions. The source is the Japan Securities Dealers Association. Details of stock acquisition rights are subsequently described

\section{Japanese individual investors' investments}


JCMS

5,1

8

million yen. As of January 2021, 136 campaigns were completed, and approximately 4.4 billion yen was raised. Figure $1 \mathrm{~b}$ illustrates the number of projects for which stock acquisition rights were issued and the amount of funds procured. Since the finalization of the first deal in December 2017, 28 investments worth approximately 800 million yen were completed as of January 2021. The growth in Japanese ECF has been particularly remarkable since 2020. To date, ECF raised 5.2 billion yen through 164 campaigns.

Originally, there were three ECF platform companies, and six more have either entered or are preparing to enter the market, suggesting the possibility of further ECF development.

\section{Prior research}

Financial literacy of individual investors

Meoli et al. (2021) examined the impact of individual investors' financial literacy on the business continuity of 432 platforms in 37 Organization for Economic Cooperation and Development (OECD) countries. They found that investors in countries with highly literate individual investors are more likely to succeed by diversifying their portfolios and reducing information asymmetry through their communication capabilities. Thus, platforms can stay in business for a long time.

According to Goethner et al. (2020), there are three types of cloud investors-sophisticated investors, casual investors and cloud enthusiasts. Although the term "literacy" does not appear in Goethner et al.'s (2020) work, the definition of "sophisticated" is almost synonymous with literacy. Goethner et al. (2021) analyzed the impact of Germany's implementation of the Small Investor Protection Act of 2015 on these three types of cloud investors. Under the act, ECF investors with over 1,000 euros of investment in Germany were required to submit income certificates, and individual investors were not allowed to invest over 10,000 euros. As a result, the participation of sophisticated investors was reduced, leaving only casual investors, thus eliminating the signal effect of sophisticated investors.

These studies are interesting because they focus on the financial literacy itself of ECF investors. Previous research typically linked individual investors' financial literacy to issuer fraud. For example, Mochkabadi and Volkmann (2020), and Hornuf and Schwienbacher (2017) wrote from the perspective of preventing fraud damage and extent of regulation. Signori and Vismara (2016) cited the case of Rebus, which went bankrupt less than one year after raising $£ 816,790$. The authorities punished some platforms in the USA (Cumming et al., 2021b). All documents filed with the US Securities and Exchange Commission (SEC) by uFP, LLC and ECF platform were flawed; furthermore, 13 of them had the same forecasted financial statements despite having different business models. Meoli and Vismara (2021) recently suggested that the platform itself may be misusing the idea of allowing bids to be canceled during the churn period. They note that the platform manipulates information by canceling bids during the cancellation period, especially in non-hot "cool" campaigns.

Although one study notes that ECF has "low fraud rates" (Block et al., 2020), most prior studies highlighting fraud by issuers and platforms inevitably call for stronger regulation. However, investors are not always victims of fraud. The investor's responsibility is to properly utilize information when issuer companies and platforms properly disclose it. However, individual investors lack sufficient literacy, of which stock issuers and platforms might take advantage when seeking to raise funds for their financial benefit. Although this does not breach relevant laws and regulations, one consequence is the free-rider problem for investors (Agrawal et al., 2014; Hornuf and Schwienbacher, 2016; Mochkabadi and Volkmann, 2020).

Gaudecker (2015) stated that people with less mathematical knowledge fail to diversify their investments and suffer greater losses. Mintjes (2016) employed an original questionnaire that supported Gaudecker's (2015) hypothesis. Professional investors thoroughly diversify their investments. If individual investors with no mathematical knowledge and low financial 
literacy do not diversify their investments, which is essential, then such investors hinder longterm ECF development (Collins and Pierrakis, 2012). The empirical findings of Meoli et al. (2021) and Goethner et al. (2021) support Collins and Pierrakis's (2012) concerns.

Vismara (2018) examined the differences in investment objectives between financially literate professional investors and individual investors. He compared the bid statuses of campaigns between ECFs that were sustainability oriented and ECFs that were not, stating that professional investors were less interested in ECFs that were sustainability oriented and that they were "market logical". He demonstrated that financially literate investors make investment decisions based on market logic or investment returns.

\section{Campaign study}

In empirical research on ECF, "campaign studies" verifying whether financing has succeeded have advanced the most (Cumming et al., 2021a; Ralcheva and Roosenboom, 2020; Venturelli et al., 2020; Wang et al., 2019). For example, Ahlers et al. (2015) analyzed 104 ECFs in Australia from 2006 to 2011 and found that the financial roadmap (the goal of seeking an initial public offering [IPO] rather than a merger and acquisition) and the percentage of shares outstanding significantly influenced the success of the campaign. Vismara (2016) analyzed samples in the United Kingdom (UK) and determined that the issue ratio negatively affected campaign success, which he interpreted as a quality signal. Vismara (2016) also showed that the founder's social network (LinkedIn) was positively correlated with campaign success, noting that social capital reduces information asymmetry in ECF campaigns. Vismara (2018) observed an information cascade in ECF, meaning that investors were getting information from other investors. He found that information is communicated in the following mannerpublic investor $\rightarrow$ early investor $\rightarrow$ late investor-indicating that the public profile of investors influences campaign success.

Walther and Bade (2020) analyzed ECF projects in Europe and found that "hot" campaigns with "large investors" attracted significantly greater funding. These campaigns were analyzed from the viewpoints of (1) geographical factors, (2) word-of-mouth and (3) risk factors. Mamonov and Malaga (2018) identified three risks to campaigns: market, execution and agency. Mamonov et al. (2017) found that effective platforms can increase ECF campaigns' success rates by reducing information asymmetry. Piva and Rossi-Lamastra (2018) argued that entrepreneurial human resources are critical to a campaign's success.

In European ECF, two campaign systems, first-come-first-served and auction bases coexist, and studies that compare both have been sporadic. For example, Hornuf and Schwienbacher (2016) analyzed 89 ECF projects in Germany and found that many were of the L-type (obtaining many investors first) on a first-come-first-served basis and the U-type (many investors gathering at the beginning and end) on an auction basis. The authors speculated that investors make decisions using additional information from entrepreneurs and previous investors on an auction basis.

Campaign studies previously described focused on the issuer's external characteristics, such as entrepreneurial qualities, patents, website attractiveness and the presence of angel investors, but not on the issuer's business plan or the share price of the issued stock. Hellmann et al. (2019) used the pre-money-market capitalization as an explanatory variable for the success or failure of a campaign but did not examine returns on the investment.

Uchida and Hayashi (2018) published a crowdfunding campaign study in Japan, although not related to ECF. The researchers analyzed data from Campfire, a reward-type crowdfunding platform in Japan, alongside Kickstarter in the USA and clarified the following three points. First, in both Japan and the USA, a campaign's success rate decreases as the target amount and number of days of the subscription increase. Active public relations increase the success rate. Second, using a video to advertise the concept effectively increases 
JCMS 5,1

campaigns' success rates in the USA but not in Japan. Third, campaigns run by entrepreneurs in the Tokyo metropolitan area have high success rates in Japan. In any case, these studies focused only on campaign (financing) success and not on the characteristics of companies using ECF or the performance of companies after engaging in ECF.

\section{Characteristics of enterprises implementing ECF}

Relative to campaign studies, fewer prior studies examined the characteristics of companies that implemented ECF. Walthoff-Borm et al. (2018a) found that some startups look toward IPOs, but others do not. The researchers examined the characteristics of enterprises implementing ECF using the pecking order hypothesis and samples from the UK. They found that enterprises aiming to use ECF have "smaller amount of internal funds," are "heavily indebted," and "have many intangible assets" compared with control firms. These characteristics indicate financial difficulties. The researchers concluded that companies that cannot borrow from banks or receive investments from VCs use ECF as a last resort. In addition, $40 \%$ of enterprises that failed to raise funds went bankrupt by the survey time; this was 2.9 times the proportion of enterprises that could raise funds and 7.2 times the proportion of enterprises that chose debt financing.

Blaseg et al. (2020) and Vismara (2019) also supported the last-resort hypothesis. They found that ECF initially attracted high-quality entrepreneurs, but the costs of information disclosure and communication with investors kept those entrepreneurs away. Instead, lowquality entrepreneurs and startups that cannot receive investments from financial institutions or VCs choose ECF as their funding source. Features of the management of such a venture corporation were the tendency to be "young" and have "little experience." Matsuo (2017a) directly interviewed three Japanese companies that raised funds using ECF. When asked about funding, two of the three companies revealed that ECF was their last resort. They stated that "Without ECF funds, it was difficult to manage the company, because it had no actual results and no collateral, so it could not receive loans from financial institutions." "Financing of funds for business expansion from financial institutions was difficult because of the deficit in the most recent fiscal year" (Matsuo, 2017a).

\section{Performance after an ECF campaign}

Studies tracking the financial and equity performance of startups after ECF are even more limited. Hornuf et al. (2018) conducted a follow-up survey of enterprises that had conducted ECF in the UK and Germany, considering the characteristics of enterprises that (1) raised additional capital and (2) subsequently went bankrupt. The results indicated that the "number of officers" and "average age of officers" were positively correlated with the "next round of funding," whereas the "number of officers" was negatively correlated with the "bankruptcy dummy." The researchers' results suggest that management's human capital is essential for the subsequent performance of ECF companies.

Signori and Vismara (2016) published an interesting study on the stock performance of companies engaged in ECF in the UK. The authors calculated the internal rate of return (IRR) from the share prices of the first and next rounds of funding. The IRR for the bankrupt sample was calculated at $-100 \%$, and the IRR for the sample that was not bankrupt but did not raise funds was calculated at $0 \%$. As a result, in 212 samples, 64 carried out seasoned equity offerings (SEOs), whereas bankruptcy was observed in 22 , and 126 shares were kept in mothballs. The IRR of the SEO samples was $63.5 \%$, and it was $8.8 \%$ when all samples were invested. In the enterprises that could engage in SEO, the following features were observed: Sales were recorded; outside directors were on the board; the outside shareholding ratio was small; and professional investors were shareholders. Walthoff-Borm et al. (2018b) compared the ex-post performance of European 
companies that had implemented ECF through one-to-one matching with similar companies as control samples. The authors compared profit margins, bankruptcies, intangible asset ratios and patent data from the fiscal year just before they raised funds (up to 2017) and found the probability of bankruptcy to be 8.5 times higher for ECF companies than for the control samples. By contrast, the authors also revealed that ECF companies obtained 3.4 times more patents and observed information asymmetry between ECF companies and investors. However, individual investors had limited ability and incentive to conduct due diligence and monitoring; this led to adverse selection.

\section{SAFE study}

SAFE stands for the simple agreement for future equity. As previously stated, SAFE is an investment technique used by VCs in Silicon Valley; the technique is intended for use by professional investors with sufficient financial literacy. However, in Japanese ECF, securities similar to SAFE — called stock acquisition rights — are issued to individual investors and are gaining popularity. SAFE is indispensable when recent financing through ECF is considered. An issuer's maximum enterprise value (valuation cap) is set in advance, and investors pay to acquire SAFE. When the issuer issues new equity finance, the SAFE held by investors is automatically converted into preferred stock up to the conversion price calculated based on the valuation cap. Table 1 summarizes the relevant parts from Saito and Yoshikawa (2017). The obvious features of SAFE are no redemption and no return on the principal (in addition, the Japanese version of SAFE has a limited exercise period). SAFE is different from convertible bonds in this respect. In addition, the conversion price for SAFE is not determined at the time of issuance but after the fact. As a result, SAFE investments are completely different from general stock options. Saito and Yoshikawa (2017) noted that the SEC's view, "Though it is called SAFE, it is neither 'Simple' nor 'Safe.' (Omission) issuers and platforms should reconsider this name." Matsuo and Umemoto (2017) outlined the SAFE concept and examined this scheme's appropriateness for investments by ECF. The researchers found that two types of companies conduct ECF: (1) technology startups that have established business models and growth trajectories and (2) non-technology companies that have difficulty attracting VCs. Among them, type (2) is not suitable for SAFE because it evolves along with a

\begin{tabular}{|c|c|c|c|}
\hline & SAFE & $\begin{array}{l}\text { Common } \\
\text { stock }\end{array}$ & Stock options \\
\hline $\begin{array}{l}\text { Interest and } \\
\text { dividends }\end{array}$ & None & Dividends & None \\
\hline Maturity & None & None & $\begin{array}{l}\text { With exercise period; expires } \\
\text { after period }\end{array}$ \\
\hline Voting right & None & Yes & None \\
\hline $\begin{array}{l}\text { Issuer obligation } \\
\text { to repay }\end{array}$ & $\begin{array}{l}\text { None *distribution at the time of } \\
\text { dissolution takes precedence over } \\
\text { shares }\end{array}$ & None & None \\
\hline Stock conversion & Time of equity financing & - & $\begin{array}{l}\text { Owner's discretion *exercise of } \\
\text { purchase right instead of } \\
\text { conversion }\end{array}$ \\
\hline Conversion price & $\begin{array}{l}\text { Undetermined *calculation based on } \\
\text { corporate value at the time of } \\
\text { conversion }\end{array}$ & - & $\begin{array}{l}\text { Exercise price determined in } \\
\text { advance }\end{array}$ \\
\hline Means of exit & Stock conversion & Sale & Exercise or sale \\
\hline
\end{tabular}

Source(s): Derived by the authors from Saito and Yoshikawa (2017, p. 73)

\section{Japanese individual investors' investments}


JCMS 5,1

founder's family business, which might not choose an IPO exit. The researchers also noted that SAFE is not appropriate for individual investors because of their degree of financial literacy.

In ECF in Japan, financing using common stock and stock acquisition rights are mainstream options. The stock acquisition rights scheme is similar to SAFE based on current knowledge (the conversion price is typically determined by the stock price of the next financing round). Matsuo (2018) explained that ECF platforms are taking steps to make this scheme easier for individual investors to understand when selling stock acquisition rights.

\section{Other comprehensive survey}

Block et al. (2018), conducted a survey on crowdfunding and noted that ECF is a research area lacking sufficient analysis. Mochkabadi and Volkmann (2020) provided a comprehensive review of ECF research development and reviewed 113 ECF papers from two perspectives. The first perspective was a descriptive statistical summary that summarized the annual number of articles, countries and regions analyzed; journals in which they were published; research methods; and other aspects. For example, the researchers' results from a focus on the research method employed indicated that approximately $40 \%$ of ECF papers used nondemonstration research, $36 \%$ used quantitative analysis, and $22 \%$ used qualitative analysis. The second perspective adopted a thematic classification that summarized the papers published to date from the viewpoints of (1) the capital market, (2) entrepreneurs, (3) institutions, (4) investors and (5) platforms. Although this study focused on investors, the analysis was further classified into five categories: incentive to invest, valuation of investment, type of investment, investment dynamics and return on investment. Signori and Vismara's (2016) work is the only available reference on return on investment, which is a focus of this paper; this indicates the scarcity of research in this area.

\section{Issues with previous research}

Although ECF's global history spans less than 10 years, research in this area continues to advance. In the field of empirical research, campaign studies have advanced the most. The types of startup companies that attract crowd investors are becoming clear, both quantitatively and qualitatively. A campaign's success or failure is very important for a startup company to obtain funding and a platform, making it necessary to clarify the related factors. Here, the most important factor from investors' perspective is the return (Block et al., 2018). Considering investment risks and returns when investing in securities, not only in ECF, is essential. These clues can be obtained by examining each company's business plan. For example, as professional investors, VCs scrutinize business plans (due diligence), estimate appropriate stock prices (valuation) and negotiate terms with startups. Due diligence and valuation capabilities are the core competencies of each VC. By contrast, many previous studies superficially evaluated crowdfunding projects and conducted lack analysis from the perspective of the due diligence or valuation that investors should be conducting.

Many studies suggested that ECF issuers and platforms misuse information asymmetry to trick individual investors. These studies propose more substantial information disclosure and strengthening of regulations as solutions. However, in these previous studies, ECF companies and platforms cited obvious false statements to deceive investors, and no previous literature exists that discusses information asymmetry after scrutiny of business plans. Although many previous studies warned that SAFE is high risk, no study examined why individual investors continue to invest in SAFE. At the same time, scant literature exists on the current growth of the ECF market from the exit perspective. The argument is that individual investors who are not financially literate invest in startups without evaluating the disclosed information, causing the free-rider phenomenon. However, to our best knowledge, 
few empirical studies have determined the relationship between individual investors' financial literacy and startup companies' and platforms' information disclosure.

Meoli et al.'s (2021) study focused on the financial literacy of ECF investors. They used the national financial literacy index, and it did not reflect only individual ECF investors. They also linked the financial literacy of individual investors to the discontinuance and survival of ECF platforms, but the performance of the platform could not be explained solely by the capabilities of the individual participating investors. In this study, the financial literacy of individual ECF investors was clarified by analyzing their participation in individual campaigns. Our research is unique in that we analyze the financial literacy of individual ECF investors based on their participation in individual campaigns, and we contribute to the deepening of ECF research by providing analytical results from a micro-perspective, which differs from Meoli et al.'s (2021) study.

\section{Hypothesis and methods}

Lack of financial literacy hypothesis

On the one hand, ECF continues to expand in Japan's financial markets. On the other hand, before the ban was lifted, whether ECF would be fully accepted by Japanese investors was widely questioned (Matsuo, 2017b). Many financial experts had the same opinion. In Europe and America, ECF was anticipated to not spread because of its large information asymmetry (Agrawal et al., 2016; Paschen, 2017; Walthoff-Borm et al., 2018a). Thus, why has this expansion of ECF differed from the aforementioned expectations? This study attempts to analyze the factors behind the expansion of the ECF market from the perspective of individual investors' financial literacy while considering previous studies' findings such as those of Meoli et al. (2021).

Several previous studies pointed out the risk that startups and ECF platforms can provide inappropriate information and harm investors (Agrawal et al., 2014, 2016; Hornuf and Schwienbacher, 2016; Blaseg et al., 2020; Meoli et al., 2021). Japan's ECF market might be expanding as a result of individual investors being deceived by such information. By contrast, ECF itself is a high-risk investment opportunity, making it natural that losses are more likely to occur in ECF than in other investment opportunities, such as listed stocks. For this reason, startups and platforms must disclose enough information to allow investors to make informed investment decisions (Löher, 2016). Investors also need to be aware of risks when making investments.

This study first examines whether the information disclosed is sufficient for individual investors to make investment decisions. The analysis items are evaluated using two factors. First, the materials disclosed by ECF are ensured to not differ from the information required by professional investors, such as VCs. Second, whether the information disclosed is analyzable is checked. Specifically, this study analyzes whether (1) the market value of shares at the time of an IPO can be estimated using a given business plan and (2) the expected return on investment can be calculated. If the results are not problematic, then the issuer or platform is considered to sincerely disclose the necessary information. In this case, the focus shifts to the financial literacy aspect of whether investors can make appropriate decisions based on disclosure materials.

For example, suppose that a risky ECF campaign that is unlikely to go public is successfully closed with the startup company or platform disclosing the information necessary for investment decisions. In that case, investors might not use that information appropriately. In other words, a lack of financial literacy causes individual investors to invest in ECF opportunities without much knowledge, possibly expanding Japan's ECF market. Literacy refers to knowledge in a specific field and the ability to utilize that information. In this study, financial literacy refers to knowledge of entrepreneurial finance and the ability to

\section{Japanese individual investors' investments}


JCMS 5,1

\section{4}

utilize it. Every year, the Venture Enterprise Center holds training sessions to learn this information and how to use it. Table 2 outlines the themes and contents of the training. Professional investors naturally operate with these forms of literacy, but that individual amateur investors have them is not guaranteed.

In this study, whether individual investors have literacy toward the concepts of due diligence and valuation is examined. Specifically, this study analyzes (1) the expected market capitalization in the final year of the business plan, which is an indicator of listing eligibility, and (2) the expected IRR if an investment is successful. In entrepreneurial finance, we must observe if the IRR is acceptable according to due diligence and valuation (Wright and Robbie, 1998; Mason and Harrison, 2002). Individual investors with due diligence literacy should not apply for ECF deals that have low expected market capitalization and are unlikely to pursue an IPO. Individual investors with valuation literacy might choose not to invest in ECF deals for which the expected IRR is not commensurate with the risk.

Prasad et al.'s (2021) model, which links financial literacy with investment decisions, identifies four elements, two of which include understanding accounting information and calculating financial returns. Furthermore, the financial literacy survey conducted by AlTamimi and Kalli (2009) for individual investors in the United Arab Emirates (UAE) includes the knowledge required to estimate the IRR in our research. Our framework is consistent with that of Prasad et al. (2021) and Al-Tamimi and Kalli (2009).

At the same time, the status of the stock acquisition rights projects is also confirmed. As many previous studies demonstrated, SAFE-the original version of Japanese stock acquisition rights - was developed for professionals with diversified investments. Individual investors who are financially literate and understand deal structures would not find it easy to invest in this area. Financially literate ECF investors prefer common stock with voting rights (Meoli et al., 2021). Conversely, in the case of Japanese stock acquisition rights, voting rights are determined later. Therefore, the success rate of the stock acquisition right's ECF is expected to be lower than that of common stocks' ECF transactions. The question that naturally extends from this is examined: What is the actual success rate for these ECF transactions? Table 3 summarizes the hypothesis and its verification methods.

\section{Data and analysis methods}

This paper analyzes 109 Japanese companies that conducted ECF campaigns from September 2017 to February 2021. For each company, the website information that its ECF platform offered was collected. Various kinds of valuation information, such as the price/

Table 2.

Venture capitalist training program overview
Contents

Method of finding investment targets

Principal items in investment contracts, such as the use of class shares

Laws that a capitalist should know about, such as compliance with insider trading regulations

How to evaluate the business plan of the investee and where to look

Valuation method at the time of investment and exit

Concept and know-how of hands-on support

Investment

leadership

Management

support

M\&A

IPO

Additional services by VCs, such as support for strategic planning, additional financing and reinforcement of human resources

$\mathrm{VC}$ mindset and negotiation process for trade sales and M\&A

VC mindset and negotiation process at IPO

Source(s): Prepared by the authors based on "JVCA 2020 Recruitment Guidelines for Venture Capitalists" 


\begin{tabular}{|c|c|c|c|c|c|}
\hline Hypothesis & Description & $\begin{array}{l}\text { Matters to be } \\
\text { verified }\end{array}$ & & $\begin{array}{l}\text { Results supporting } \\
\text { the hypothesis }\end{array}$ & $\begin{array}{l}\text { Japanese } \\
\text { individual }\end{array}$ \\
\hline \multirow[t]{7}{*}{$\begin{array}{l}\text { Lack of } \\
\text { financial } \\
\text { literacy } \\
\text { hypothesis }\end{array}$} & \multirow{7}{*}{$\begin{array}{l}\text { Individual investors } \\
\text { are investing in ECF } \\
\text { projects without } \\
\text { sufficient financial } \\
\text { literacy although } \\
\text { disclosure by issuers } \\
\text { and platforms is } \\
\text { considered appropriate }\end{array}$} & \multirow[t]{3}{*}{$\begin{array}{l}\text { Status of } \\
\text { information } \\
\text { disclosure }\end{array}$} & $\begin{array}{l}\text { Contents of the disclosed } \\
\text { information }\end{array}$ & \multirow{4}{*}{$\begin{array}{l}\text { Information } \\
\text { disclosed in ECF is } \\
\text { equivalent to that } \\
\text { disclosed to VCs } \\
\text { Information } \\
\text { disclosed in ECF } \\
\text { can be analyzed } \\
\text { with financial } \\
\text { literacy } \\
\text { No correlation }\end{array}$} & investments \\
\hline & & & \multirow[t]{2}{*}{$\begin{array}{l}\text { Whether the information } \\
\text { can be analyzed }\end{array}$} & & 15 \\
\hline & & & & & \\
\hline & & \multirow[t]{4}{*}{$\begin{array}{l}\text { Utilization of } \\
\text { disclosed } \\
\text { information }\end{array}$} & $\begin{array}{l}\text { Correlation between } \\
\text { expected market } \\
\text { capitalization at IPO (i.e. } \\
\text { whether or not an IPO is } \\
\text { possible) obtained as a } \\
\text { result of due diligence } \\
\text { and the success or failure } \\
\text { of projects }\end{array}$ & & \\
\hline & & & $\begin{array}{l}\text { Correlation between the } \\
\text { results of valuations (i.e. } \\
\text { expected IRR) and the } \\
\text { success or failure of } \\
\text { projects }\end{array}$ & No correlation & \\
\hline & & & $\begin{array}{l}\text { Correlation between deal } \\
\text { structure (i.e. common }\end{array}$ & No correlation & \\
\hline & & & $\begin{array}{l}\text { stock or stock acquisition } \\
\text { rights) and the success or } \\
\text { failure of projects }\end{array}$ & & $\begin{array}{r}\text { Table 3. } \\
\text { Hypothesis and } \\
\text { analysis items }\end{array}$ \\
\hline
\end{tabular}

earnings $(\mathrm{P} / \mathrm{E})$ ratio at IPO, were obtained from the "IPO White Paper" on ProNexus. The degree of information disclosure was verified by comparing the information available to individual investors through ECF with the information available to professional VCs when they consider an investment. In ECF, all information is disclosed on the web. This information was obtained, and its contents were examined.

The prospect of an exit through an IPO is judged using a company's business plan. For an enterprise to engage in an IPO, the company's performance must satisfy the listing standard. Although listing standards differ depending on the stock market, many markets have market capitalization standards. The Tokyo Stock Exchange (TSE) Mothers section, targeted by many Japanese ECF companies, set the market capitalization standard at 1 billion yen or more at the time of listing. In this study, the expected market capitalization of shares at the time of an IPO is estimated if the business performance progresses according to the business plan, and whether its capital exceeds 1 billion yen is determined. Market capitalization is estimated by multiplying the net income for the business plan's final fiscal year by the $\mathrm{P} / \mathrm{E}$ ratios assumed at the time of the IPO. The $\mathrm{P} / \mathrm{E}$ ratios are based on 770 companies listed on Japanese stock markets between 2003 and 2020. Table 4 lists P/E ratios of 770 companies by industry. The median value of the relevant industry is used for the samples.

The expected return for each stock is focused on to determine whether the campaign provided an adequate investment return. Professional investors, such as VCs, conduct detailed due diligence on individual transactions and generally negotiate privately with companies based on stock prices (valuation) in accordance with expected returns. By contrast, in ECF, the issuer company offers the stock price in advance, and investors invest in 
JCMS

5,1

\begin{tabular}{|c|c|c|c|c|}
\hline Sector & $n$ & Min & Median & Max \\
\hline Services & 160 & 0.2 & 39.8 & 1,732 \\
\hline Information and communication & 140 & 4.7 & 50.6 & 2,483 \\
\hline Retail trade & 82 & 1.8 & 25.9 & 7,417 \\
\hline Real estate & 68 & 2.1 & 24.9 & 1,718 \\
\hline Wholesale trade & 65 & 3.9 & 20.8 & 643 \\
\hline Electric appliances & 31 & 8.5 & 28.4 & 11,364 \\
\hline Machinery & 27 & 1.8 & 18.8 & 160 \\
\hline Chemicals & 26 & 3.8 & 13.7 & 923 \\
\hline Other products & 22 & 7.5 & 19.7 & 156 \\
\hline Construction & 20 & 4.5 & 22.3 & 234 \\
\hline Other financing business & 17 & 9.7 & 19.2 & 205 \\
\hline Securities and commodities futures & 14 & 2.2 & 24.6 & 745 \\
\hline Land transportation & 12 & 5.1 & 27.4 & 525 \\
\hline Foods & 11 & 9.9 & 18.6 & 679 \\
\hline Precision instruments & 11 & 10.1 & 25.4 & 74 \\
\hline Banks & 9 & 4.8 & 13.7 & 104 \\
\hline Pharmaceutical & 7 & 12.0 & 25.1 & 234 \\
\hline Textiles and apparels & 7 & 7.4 & 16.7 & 31 \\
\hline Warehousing and harbor transportation & 7 & 4.8 & 17.4 & 38 \\
\hline Transportation equipment & 7 & 4.2 & 14.8 & 28 \\
\hline Metal products & 5 & 9.1 & 19.5 & 34 \\
\hline Nonferrous metals & 5 & 8.2 & 18.5 & 25 \\
\hline Electric power and gas & 4 & 6.4 & 9.9 & 11,591 \\
\hline Insurance & 4 & 18.4 & 54.8 & 197 \\
\hline Glass and ceramics products & 2 & 12.0 & 18.7 & 25 \\
\hline Pulp and paper & 2 & 13.4 & 44.2 & 75 \\
\hline Air transportation & 2 & 3.7 & 6.2 & 9 \\
\hline Others & 1 & 12.8 & 12.8 & 13 \\
\hline Mining & 1 & 29.4 & 29.4 & 29 \\
\hline Fishery, agriculture and forestry & 1 & 53.4 & 53.4 & 53 \\
\hline Total & 770 & 0.2 & 27.4 & 11,591 \\
\hline
\end{tabular}

Table 4.

Total

770

0.2

11,591

Initial P/E ratio at IPO Source(s): Prepared by the authors from the white paper on stock listings (ProNexus)

the stock if they judge that its price is worth the risk. Therefore, the expected IRR is estimated by assuming that each startup grows according to its business plan and goes public - called the VC method, which is commonly used in practice (Sammut, 2012; Sander and Kõomägi, 2007; Smith et al., 2011).

Professional VCs require an IRR of 50\%-100\% for seed and startup companies and $30 \%-$ $60 \%$ for early-stage companies. Whether similar IRRs can be expected in ECF projects was evaluated. Specifically, the estimated IRR was confirmed to be not significantly lower than the IRR standards of VCs, who are professionals in investing in unlisted companies. The IRR formula is provided in Eqn (1). The estimated market capitalization at the time of an IPO is the amount estimated by analyzing the expected listing. An IRR is the compound annual rate of interest on the amount invested.

$$
\begin{aligned}
& \text { Estimated stock market value at the IPO } \times \text { stock holding ratio } \\
& \quad=\text { investment amount } \times(1+\mathrm{IRR})^{n}
\end{aligned}
$$

In Eqn (1), $n$ is the number of years between the investment and the IPO, and the investment amount is the stock price multiplied by the number of shares offered by each offering campaign. 
For convenience, this study conducted calculations based on the assumption that one investor acquires all shares issued in the campaign. The shareholding ratio is calculated by dividing the number of newly issued shares by the number of shares outstanding + the number of newly issued shares + the number of stock options at the time of the campaign. In addition, many startup companies raise additional equity financing as they grow, thereby diluting their original equity stake. An adjustment method is subsequently described for this dilution.

\section{Results}

\section{Information disclosed}

Is there serious information asymmetry between ECF companies and individual investors? Is there a difference between the information that professional investors, such as VCs, obtain and the information that individual investors obtain? To answer these questions, the information that investors can receive through ECF was investigated. VCs engage in their due diligence based on the information they receive. By contrast, for ECF, the ECF platform acts as an intermediary, and the information is provided to individual investors after the platform sorts through it. Each platform has established and published handling guidelines for ECF operations and reviews campaigns based on the Japan Securities Dealers Association's Regulation on equity crowdfunding.

Table 5 compares the materials and information that issuers provide to VCs with the information that issuers provide to individual investors during ECF. The materials provided to VCs include articles of incorporation, certified copies of the registry, statements of accounts, tax returns, monthly trial balances, business plans, cash flow tables, capital policies, shareholder registries, executive resumes and patent lists. These features are similar to the data that ECF provides. A certified public accountant's short review report is required by the VC immediately before the enterprise engages in an IPO. However, during the seed and startup ECF stages, no short review from a certified public accountant is used and, thus, is not required. In ECF, issuers who pass the platform's examination disclose information on their business; the external environment, such as the business's market; their superiority; their business model; settlement of their accounts; their business plan; names and careers of their officers; and their shareholders, fund use, goals of key performance indicators (e.g. sales

\begin{tabular}{|c|c|c|}
\hline Materials provided by the issuer & $\mathrm{VC}$ & $\mathrm{ECF}$ \\
\hline Articles of incorporation & 0 & $\Delta$ \\
\hline Certified copy of registry & 0 & $\Delta$ \\
\hline Financial statement & 0 & 0 \\
\hline Tax return & 0 & $\Delta$ \\
\hline Monthly trial balance & 0 & $\Delta$ \\
\hline Business plan & 0 & 0 \\
\hline Cash flow statement & 0 & $\Delta$ \\
\hline Capital policy & 0 & 0 \\
\hline Shareholder registry & 0 & 0 \\
\hline Officer's resume & 0 & 0 \\
\hline List of patents & 0 & $\Delta$ \\
\hline Report of short review by certified & & \\
\hline Public accountants and auditing firm & $\bigcirc$ & $\mathrm{X}$ \\
\hline Materials related to the company's & & \\
\hline Products and services and technologies & 0 & $\Delta$ \\
\hline
\end{tabular}

Table 5. Materials provided by issuer to VCs and ECF
Japanese individual investors' investments 
JCMS 5,1

\section{8}

volume) and risk of investment to small investors registered on each platform. In particular, the business plan discloses key items in the income statement, balance sheet and cash flow statement for the next five years (but there are exceptions). In other words, the information received by the $\mathrm{VC}$ - a professional investor - and the information received by the individual investor who invests in ECF are almost equivalent. Thus, issuers are unlikely to use information asymmetry to encourage ECF investors to invest.

\section{Is the disclosed information analyzable?}

Table 6 presents the estimated market value of $96 \mathrm{ECF}$ companies' stocks in the final years of their business plans. The median value is 9.6 billion yen; the minimum is 276 million yen; and the maximum is 259.6 billion yen. The sample data indicate that financially literate investors could estimate the market capitalization at the time of the IPO and that the information is analyzable. Therefore, the issue shifts to whether individual investors have the ability to scrutinize the information they obtain and make appropriate investment decisions.

The expected IRR in Table 7 estimates the expected IRRs of 60 ECF companies. The companies in the sample were determined to be in the startup or early stages. For companies in these stages, professional VCs require an annual IRR of 30\%-100\%. The minimum and maximum expected IRRs of the study samples were $7 \%$ and $223 \%$, respectively. Thus, this sample could be used to estimate the rate of return on investments for investors with sufficient financial literacy.

Moreover, the assumption for the expected IRR in Table 7 is somewhat unreasonable because post-investment dilution is not considered. Startups typically raise funds in line with their growth stage until their IPO. If funds are raised using equity, then the current shareholding ratio decreases and becomes diluted. The degree of dilution varies from firm to firm. According to Coral Capital (2019), Series A, B, C and D rounds of financing for a Japanese startup dilute the company's stock by $14.93 \%, 18.37 \%, 13.29 \%$ and $12.21 \%$, respectively (median basis). Most of Japan's ECF occurs during a company's first round of funding. If the funding to be analyzed is assumed to be Series A and that Series B to Series D rounds will occur before listing, then the dilution ratio in the future can be estimated as $118.37 \% \times 113.29 \% \times 112.21 \%=$ approximately $150 \%(1.1837 \times 1.1329 \times 1.1221)$. In the subsequent analysis, the expected IRR is calculated by incorporating a $50 \%$ share dilution. The diluted expected IRR in Table 7 is the expected diluted IRR of 60 ECF companies. The predicted IRR after dilution was a minimum of $-5 \%$ and a maximum of $194 \%$. In the meantime, that a startup company's stock becomes gradually diluted might not be foreseeable unless the investor is financially literate.

These analyses proved the following three points. First, the information disclosed in ECF campaigns is at a level consistent with that obtained by VCs. Second, ECF companies' market capitalization at their IPOs can be estimated from their business plans. Third, the return on ECF can also be estimated. These results suggest that ECF campaigns provide all of the information necessary for investment decisions. The question then shifts to whether individual investors can scrutinize and verify the information provided about a business plan's reliability.

\section{Is information being used by individual investors?}

The initial market capitalization of the 94 companies that went public on the TSE Mothers section between 2018 and 2020 was a minimum 1.7 billion yen, an average 17.1 billion yen and a maximum 163.4 billion yen. All of these companies met the 1 billion yen listing requirement. Is the ECF sample expected to also have a market capitalization higher than the listing threshold? Table 6 lists the estimated market values of 96 ECF companies' stocks in the final years of their business plans. The minimum amount was expected to be 280 million yen, and 4 


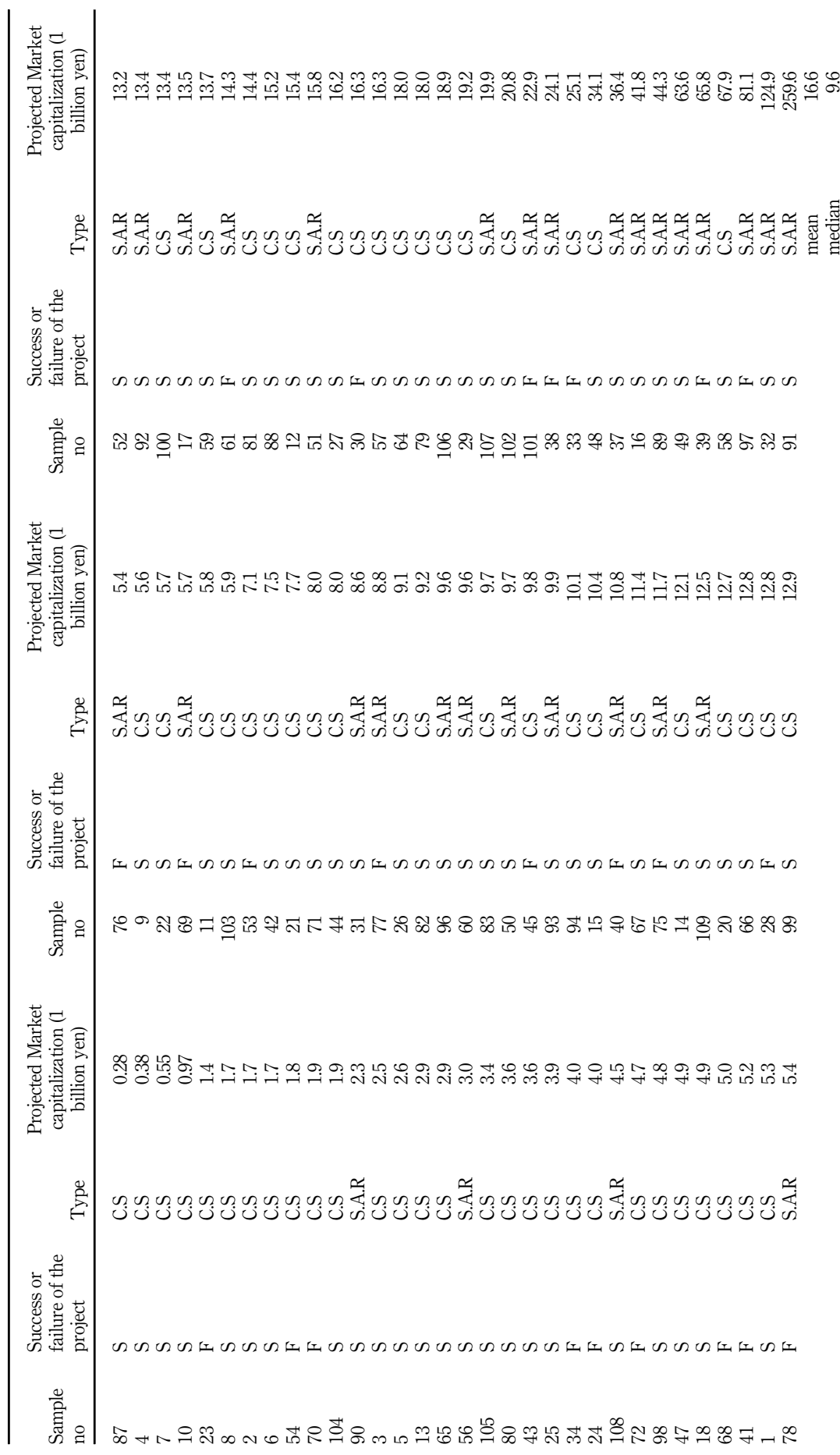


JCMS

5,1

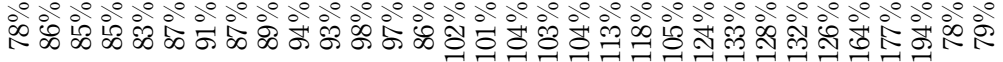

言

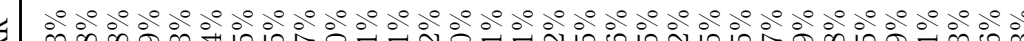

ஜ் 悉

ดु

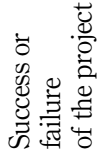

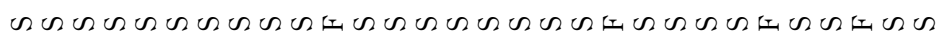

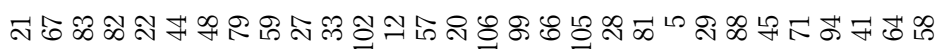

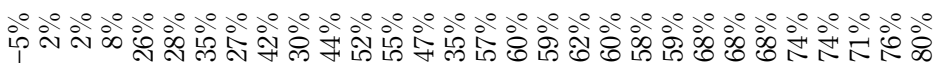

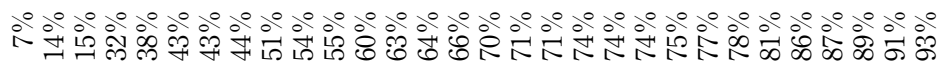

Table 7.

Expected IRRs of 60 ECF companies

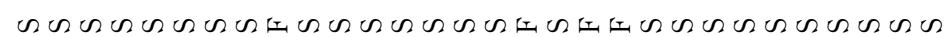

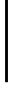

के

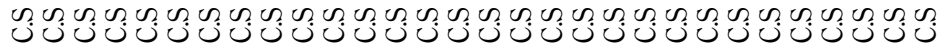


out of 96 companies failed to reach the listing standard of 1 billion yen. In other words, projects that were not expected to go public succeeded in raising funds. Table 7 provides the expected IRRs. VCs require 50\%-100\% IRRs for seed to startup companies and 30\%-60\% IRRs for early-stage companies. Three pre-dilution and six post-dilution IRRs accounted for less than $30 \%$ of the expected IRRs. One was estimated as a negative IRR on a post-dilution basis. However, those projects were successful. Many samples are considered at the seed or startup stage; thus, on a $50 \%$ basis, five pre-diluted and seven post-diluted companies raised money even though the IRR is below the reference value.

Of course, the platforms repeatedly announce the risk of an investee company not being able to list, and investors are supposed to know the risks when they apply. However, Mintjes (2016), Matsuo (2017b), and other researchers have demonstrated that investors ultimately expect a stock return from ECF. In 7 out of 96 companies, the listing possibilities and/or investment returns seemed low, even if the business plans were achieved. However they succeeded in financing. This finding suggests that investors might have made investments without using public information.

Next, panel A in Table 8 displays results of tabulating the estimated market value of stocks in the business plan's final fiscal year by dividing the year into 72 successful and 24 unsuccessful cases. The average amount of approved projects totaled 17.2 billion yen, whereas unsuccessful projects totaled 14.8 billion yen. Despite not being statistically significant, the market capitalization of failed projects was found to be higher. Analysis using median values indicated similar trends. Panel B in Table 8 provides the results of tabulating the diluted expected IRR of the campaigns after dividing the total into 52 successful cases and 8 unsuccessful cases. The average of successful projects was $76.3 \%$, whereas that of unsuccessful projects was $90.3 \%$. Although no significant difference existed, the expected IRR was higher for failed projects. An analysis using median values showed similar trends. These results indicate that even projects with higher capital gains and IRRs might not be successful. At the very least, capital gains and IRRs are assumed not to be factors affecting individual investors' decisions to invest.

\section{Stock acquisition rights that are popular with individual investors}

In ECF in Japan, trading common stocks is the most common option used; however, trading stock acquisition rights is increasing. Stock acquisition rights are securities with equivalent functions and characteristics as the SAFE investments introduced earlier. In Japan, 42 projects have been developed to date, and financing has succeeded in 28 projects. SAFE is regarded as "neither 'Simple' nor 'Safe" and "not appropriate for small investors due to literacy" (Matsuo and Umemoto, 2017). When investments are made in subscription rights to shares through ECF, the price for the conversion into shares should not be fixed at the time of investment and must be set at a later date (mainly during the next equity financing round). In this study, the expected return of each project based on the IRR is estimated; this requires the stock price at the time of the investment. The IRR cannot be estimated using this study's method (the VC method) because prices of stock acquisition rights cannot be determined at the time of investment. More complex models of estimating returns might exist, but they are not easy for individual investors to use.

Table 9 presents the composition of approved and rejected projects divided by shares and subscription rights for all ECF campaigns in Japan. In total, $71.9 \%$ of the common stock projects and $72.1 \%$ of the stock acquisition rights projects were completed. No significant difference was found when the chi-squared test was performed for each composition ratio. These results suggest that individual investors might treat as similar common stock projects and more risky stock acquisition rights projects.

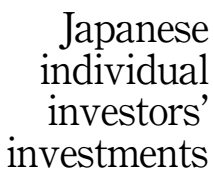


JCMS

5,1

\section{2}

Table 8.

Estimated equity market value and expected IRR divided by project success or failure

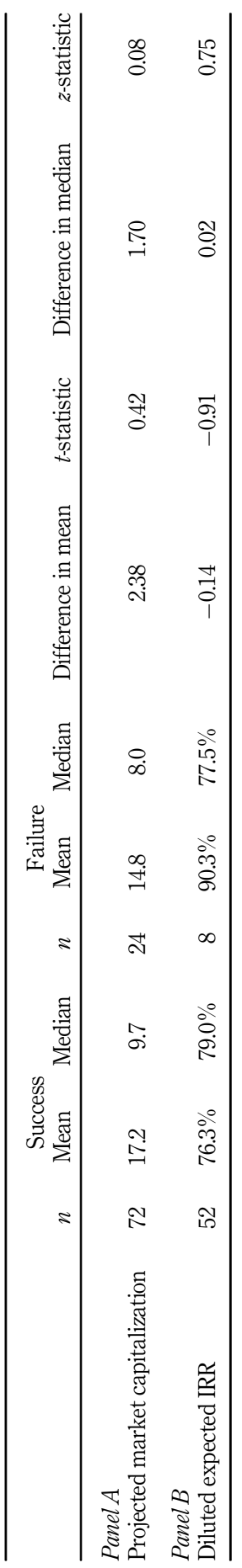


Stock acquisition rights are widely accepted in Japan's ECF market. The success rate of the campaign and the total amount of funding raised are notable, as is the short campaign period. Recently, SkyNow Co., Ltd. raised its target amount of money in $43 \mathrm{~min}$, and Dornut Robotics Co., Ltd. achieved its goal in $18 \mathrm{~min}$. The researchers believe that stock acquisition rights are not appropriate for individual investors in terms of financial literacy. However, at present, individual investors accept stock acquisition rights for shares; this is considered to be evidence of a lack of financial literacy.

These analyses highlight the following three points. First, projects of companies that do not expect to conduct an IPO, even if they achieve their business plans, and those with low expected returns are successful. Second, when business plans are examined individually, projects that require plan modifications and have low expected returns are also successfully funded. Third, investors invest in stock acquisition rights projects for which the expected returns cannot be easily estimated and common stock projects the same way. These projects can be easily analyzed using the information disclosed at the time of the ECF offering, if investors have sufficient financial literacy. In ECF in Japan, although information disclosure is carried out to some extent, individual investors cannot effectively utilize this information. This study also found support for the lack of financial literacy hypothesis.

\section{Conclusions}

This study analyzed (1) the status of information disclosure and (2) the availability of information for $109 \mathrm{ECF}$ projects in Japan. For (1) information disclosure, the focus was on not only whether a project meets legal requirements but also whether the project can be analyzed to make profitable investment decisions. More concretely, the expected market capitalization of stocks and expected IRR in the last fiscal year of the business plan was confirmed to be estimable. As a result, issuers and platforms were found to provide individual investors with information comparable to that available to VCs. Thus, financially literate investors can estimate the expected market value of common stocks and the expected IRR. For (2) the availability of information, projects' IPO potential and expected IRRs were confirmed from the perspective of due diligence and valuation. As a result, even projects with a successful business plan but for which an IPO was difficult or lacking a return commensurate with the risk were successfully funded. Next, the estimated market value of stocks in the business plan's final fiscal year was compared by dividing the year into successful and unsuccessful cases. The expected IRR of the campaigns was also calculated after dividing the total into successful and unsuccessful cases. Although no significant difference exists, the expected IRR was higher for failed projects. At the very least, capital gains and IRRs are assumed to not be factors used by individual investors when making investment decisions.

Stock acquisition rights for which the expected IRR is difficult to estimate are also favorable for ECF. If individual investors had analyzed disclosed information in a similar manner to that of professional investors, then some projects would have been avoided. However, such projects were completed, suggesting that individual investors participating in ECF might not be able to effectively use public information. These results support the lack of financial literacy hypothesis. They may be casual investors (Block et al., 2020.).

\begin{tabular}{lrrrrr}
\hline & \multicolumn{2}{c}{ Success } & & Failure & Total \\
\hline Common stock & 141 & $71.9 \%$ & 55 & $28.1 \%$ & 196 \\
Stock acquisition rights & 31 & $72.1 \%$ & 12 & $27.9 \%$ & 43 \\
Total & 172 & $72.0 \%$ & 67 & $28.0 \%$ & 239
\end{tabular}

Table 9.

Success rate by project type 
JCMS 5,1
This study estimated the expected return and IPO potential of each ECF project by conducting initial due diligence on each project plan and present quantitative data. This finding is not found in previous studies that only analyzed the superficial characteristics of a campaign. At the same time, the results suggest that Japanese retail investors might, after all, be blindly investing in ECF with little understanding of each campaign. The expansion of ECF is progressing not only in Japan but also globally. Other countries that have a background similar to Japan represent a major problem that needs to be addressed globally. Improving individual investors' financial literacy might be required in all countries.

In contrast, this study also demonstrated that the platform actually provides enough information for individual investors to perform initial due diligence and valuation on each ECF project. In other words, individual investors can engage in the same degree of due diligence and valuation as do VCs, as long as they use such information. If due diligence is carried out, the project's success rate decreases. Projects involving stock acquisition rights for which investment returns cannot be estimated are likely to be avoided. If ECF is used effectively, it will help revitalize Japanese startups that historically had very few investors. ECF could also be an attractive new option for Japanese retail investors who have faced low interest rates for more than 20 years. However, if investors simply invest on the basis of the novelty of a project's appearance and the aesthetics of its web page, then those investors eventually experience numerous failures, and the new funding methods that have emerged are undermined. This is because in the ECF market, in which only casual investors lacking financial literacy participate, investors cannot distinguish between good and bad startups (Block et al., 2020).

ECF was originally a risky investment method used by professional $\mathrm{VC}$ and angel investors. Thus, Japanese retail investors should acquire sufficient financial literacy to properly engage in ECF. The financial industry and the government should also actively help investors acquire sufficient financial literacy. For example, an ECF platform should provide investors with sufficient knowledge regarding due diligence and valuation that they should be aware about. Regular seminars and e-learning opportunities should be provided. Further, individual investors should be allowed to open an ECF account only if they have correctly answered due diligence and valuation questions. The problem is not a simple arithmetic one, and it is desirable to calculate the IRR for actual past projects. In the case of ECF in Japan, all investors are anonymous. Unlike European ECF, prominent investors are not upstream in the information cascade. Therefore, it is important to encourage casual investors to become sophisticated investors. With an increase in the number of anonymous but sophisticated investors, the "wisdom of the crowd" will be put to work.

Finally, the limitations of this study are as follows. This study highlights the lack of financial literacy among ECF investors in Japan and proposes ideas to improve their due diligence and valuation skills. However, these methods are quite simple, and they are, in fact, different from those of professional investors like venture capitalists. We must examine the investment performance of ECF projects over the next $4-5$ years to determine whether our findings and proposals are appropriate. Additionally, in this study, those who invested in stock acquisition rights were considered to have low financial literacy, but they should be judged on the basis of stock prices in the next equity financing round.

This study was based on the assumption that there was no platform or startup fraud. However, in previous studies, fraud is a leading hypothesis. Japan's ECF market may be developing because of multiple factors. Therefore, it is essential to analyze hypotheses in consideration of a combination of factors. In this sense, our study only revealed some of the characteristics of Japan's ECF market, and many issues remain to be addressed. The authors have conducted further analysis, and these results will be reported in our next paper. 


\section{References}

Adhikary, B.K., Kutsuna, K. and Hoda, T. (2018), Crowdfunding: Lessons from Japan's Approach, Springer Singapore, Singapore.

Agrawal, A., Catalini, C. and Goldfarb, A. (2014), "Some simple economics of crowdfunding", Innovation Policy and the Economy, Vol. 14 No. 1, pp. 63-97.

Agrawal, A., Catalini, C. and Goldfarb, A. (2016), "Are syndicates the killer app of equity crowdfunding?”, California Management Review, Vol. 58 No. 2, pp. 111-124.

Ahlers, G.K., Cumming, D., Günther, C. and Schweizer, D. (2015), "Signaling in equity crowdfunding", Entrepreneurship Theory and Practice, Vol. 39 No. 4, pp. 955-980.

Al-Tamimi, H.A.H. and Kalli, A.A.B. (2009), "Financial literacy and investment decisions of UAE investors", The Journal of Risk Finance, Vol. 10 No. 5, pp. 500-516.

Blaseg, D., Cumming, D. and Koetter, M. (2020), "Equity crowdfunding: high-quality or low-quality entrepreneurs?", Entrepreneurship Theory and Practice, Vol. 45 No. 3, pp. 505-530.

Block, J.H., Colombo, M.G., Cumming, D.J. and Vismara, S. (2018), "New players in entrepreneurial finance and why they are there", Small Business Economics, Vol. 50 No. 2, pp. 239-250.

Block, J.H., Groh, A., Hornuf, L., Vanacker, T. and Vismara, S. (2020), "The entrepreneurial finance markets of the future: a comparison of crowdfunding and initial coin offerings", Small Business Economics. doi: 10.1007/s11187-020-00330-2.

Bruton, G., Khavul, S., Siegel, D. and Wright, M. (2015), "New financial alternatives in seeding entrepreneurship: microfinance, crowdfunding, and peer-to-peer innovations", Entrepreneurship Theory and Practice, Vol. 39 No. 1, pp. 9-26.

Collins, L. and Pierrakis, Y. (2012), "The venture crowd: crowdfunding equity investments into business", Nesta, June, pp. 1-36.

Coral Capital (2019), Japan Startup Deal Terms Summer 2019, Coral Capital, Tokyo.

Cumming, D., Meoli, M. and Vismara, S. (2021a), "Does equity crowdfunding democratize entrepreneurial finance?”, Small Business Economics, Vol. 56, pp. 533-552.

Cumming, D.J., Vanacker, T. and Zahra, S.A. (2021b), "Equity crowdfunding and governance: toward an integrative model and research agenda", Academy of Management Perspectives, Vol. 35 No. 1, pp. 69-95.

Drover, W., Busenitz, L., Matusik, S., Townsend, D., Anglin, A. and Dushnitsky, G. (2017), “A review and road map of entrepreneurial equity financing research: venture capital, corporate venture capital, angel investment, crowdfunding, and accelerators", Journal of Management, Vol. 43 No. 6, pp. 1820-1853.

Gaudecker, H.M.V. (2015), "How does household portfolio diversification vary with financial literacy and financial advice?”, The Journal of Finance, Vol. 70 No. 2, pp. 489-507.

Goethner, M., Luettig, S. and Regner, T. (2020), "Crowdinvesting in entrepreneurial projects: disentangling patterns of investor behavior", Small Business Economics. doi: 10.1007/s11187020-00332-0.

Goethner, M., Hornuf, L. and Regner, T. (2021), "Protecting investors in equity crowdfunding: an empirical analysis of the small investor protection act", Technological Forecasting and Social Change, Vol. 162, 120352.

Hellmann, T., Mostipan, I. and Vulkan, N. (2019), "Be careful what you ask for: fundraising strategies in equity crowdfunding", SSRN Working Paper, available at: https://papers.ssrn.com/sol3/ papers.cfm?abstract_id $=3448596$.

Hornuf, L. and Schwienbacher, A. (2016), “Crowdinvesting: angel investing for the masses?", Handbook of Research on Business Angels, Edward Elgar Publishing, Cheltenham.

Hornuf, L. and Neuenkirch, M. (2017), "Pricing shares in equity crowdfunding", Small Business Economics, Vol. 48 No. 4, pp. 795-811. 
JCMS 5,1

Hornuf, L. and Schwienbacher, A. (2017), "Should securities regulation promote equity crowdfunding?", Small Business Economics, Vol. 49 No. 3, pp. 579-593.

Hornuf, L., Schmitt, M. and Stenzhorn, E. (2018), "Equity crowdfunding in Germany and the United Kingdom: follow-up funding and firm failure", Corporate Governance: An International Review, Vol. 26 No. 5, pp. 331-354.

Löher, J. (2016), "The interaction of equity crowdfunding platforms and ventures: an analysis of the preselection process", Venture Capital, Vol. 19 Nos 1-2, pp. 51-74.

Lukkarinen, A., Teich, J.E., Wallenius, H. and Wallenius, J. (2016), "Success drivers of online equity crowdfunding campaigns", Decision Support Systems, Vol. 87, pp. 26-38.

Mamonov, S. and Malaga, R. (2018), "Success factors in Title III equity crowdfunding in the United States", Electronic Commerce Research and Applications, Vol. 27, pp. 65-73.

Mamonov, S., Malaga, R. and Rosenblum, J. (2017), "An exploratory analysis of Title II equity crowdfunding success”, Venture Capital, Vol. 19 No. 3, pp. 239-256.

Mason, C.M. and Harrison, R.T. (2002), "Is it worth it? The rates of return from informal venture capital investments", Journal of Business Venturing, Vol. 17 No. 3, pp. 211-236.

Matsuo, J. (2017a), "Investment-based crowdfunding and venture development", The JSRI Journal of Financial and Securities Markets, Vol. 100, pp. 55-74.

Matsuo, J. (2017b), "New developments in investment-based crowdfunding", Sho-Ken Report, Vol. 1704, pp. 1-20.

Matsuo, J. (2018), “Cloud SAFE in Japan”, Sho-Ken Report, Vol. 1706, pp. $28-49$.

Matsuo, J. and Umemoto, T. (2015), "Regulations on investment-based crowdfunding", The JSRI Journal of Financial and Securities Markets, Vol. 91, pp. 45-61.

Matsuo, J. and Umemoto, T. (2017), "Simple agreement of future equity (SAFE) and crowdfunding", The JSRI Journal of Financial and Securities Markets, Vol. 99, pp. 1-17.

Meoli, M. and Vismara, S. (2021), "Information manipulation in equity crowdfunding markets", Journal of Corporate Finance, Vol. 67, 101866.

Meoli, M., Rossi, A. and Vismara, S. (2021), "Financial literacy and security-based crowdfunding", Corporate Governance: An International Review. doi: 10.1111/corg.12355.

Mintjes, D. (2016), "The role of financial literacy on portfolio diversification in peer-to-peer lending", Working Paper, available at: Semantic Scholar, https://www.semanticscholar.org/.

Mochkabadi, K. and Volkmann, C.K. (2020), "Equity crowdfunding: a systematic review of the literature”, Small Business Economics, Vol. 54 No. 1, pp. 75-118.

Paschen, J. (2017), "Choose wisely: crowdfunding through the stages of the startup life cycle", Business Horizons, Vol. 60 No. 2, pp. 179-188.

Piva, E. and Rossi-Lamastra, C. (2018), "Human capital signals and entrepreneurs' success in equity crowdfunding", Small Business Economics, Vol. 51 No. 3, pp. 667-686.

Prasad, S., Kiran, R. and Sharma, R.K. (2021), "Influence of financial literacy on retail investors' decisions in relation to return, risk and market analysis", International Journal of Finance and Economics, Vol. 26 No. 2, pp. 2548-2559.

Ralcheva, A. and Roosenboom, P. (2020), "Forecasting success in equity crowdfunding", Small Business Economics, Vol. 55, pp. 39-56.

Saito, Y. and Yoshikawa, H. (2017), "Growing equity crowdfunding in the U.S", Nomura Capital Market Quarterly, Vol. 21, pp. 68-86.

Sammut, S.M. (2012), "Valuation methods in early-stage biotechnology enterprises: the 'venture capital method' at work", Journal of Commercial Biotechnology, Vol. 18 No. 2, pp. 78-82.

Sander, P. and Kõomägi, M. (2007), "Valuation of private companies by Estonian private equity and venture capitalists", Baltic Journal of Management, Vol. 2 No. 1, pp. 6-19. 
Signori, A. and Vismara, S. (2016), "Returns on investments in equity crowdfunding", SSRN Working Paper, available at: https://papers.ssrn.com/sol3/papers.cfm?abstract_id=2765488.

Smith, J., Smith, R.L., Smith, R. and Bliss, R. (2011), Entrepreneurial Finance: Strategy, Valuation, and Deal Structure, Stanford University Press, Redwood City, CA.

Uchida, Y. and Hayashi, T. (2018), "Success factors in crowdfunding: an empirical study and comparisons in Japan and US", Akamon Management Review, Vol. 17, pp. 209-22.

Venturelli, V., Pedrazzoli, A. and Gallo, G. (2020), "Birds of a feather flock together: the inclusive effect of similarity patterns in equity crowdfunding", Sustainability, Vol. 12 No. 9, 3539.

Vismara, S. (2016), "Equity retention and social network theory in equity crowdfunding", Small Business Economics, Vol. 46 No. 4, pp. 579-590.

Vismara, S. (2018), "Information cascades among investors in equity crowdfunding", Entrepreneurship Theory and Practice, Vol. 42 No. 3, pp. 467-497.

Vismara, S. (2019), "Sustainability in equity crowdfunding", Technological Forecasting and Social Change, Vol. 141, pp. 98-106.

Walther, M. and Bade, M. (2020), "Observational learning and willingness to pay in equity crowdfunding", Business Research, Vol. 13 No. 2, pp. 639-661.

Walthoff-Borm, X., Schwienbacher, A. and Vanacker, T. (2018a), "Equity crowdfunding: first resort or last resort?", Journal of Business Venturing, Vol. 33 No. 4, pp. 513-533.

Walthoff-Borm, X., Vanacker, T. and Collewaert, V. (2018b), "Equity crowdfunding, shareholder structures, and firm performance”, Corporate Governance: An International Review, Vol. 26 No. 5, pp. 314-330.

Wang, W., Mahmood, A., Sismeiro, C. and Vulkan, N. (2019), "The evolution of equity crowdfunding: insights from co-investments of angels and the crowd", Research Policy, Vol. 48 No. 8, 103727.

Wright, M. and Robbie, K. (1998), "Venture capital and private equity: a review and synthesis", Journal of Business Finance and Accounting, Vol. 25 Nos 5-6, pp. 521-570.

\section{Corresponding author}

Yoshiaki Nose can be contacted at: ynose@mail.doshisha.ac.jp
Japanese individual investors' investments 